\title{
Influence of school leadership, discipline, and work motivation toward high school teacher performance
}

\author{
Theresia Titik Setiyaningsih * \\ Dinas Sosial Kabupaten Sleman. \\ J1. Parasamya, Beran, Tridadi, Sleman, Yogyakarta 55511, Indonesia. \\ theresiatitik55@gmail.com \\ * Corresponding Author
}

\section{ARTICLE INFO}

\section{Article History}

Received:

23 March 2017;

Revised:

31 March 2020;

Accepted:

2 April 2020

\section{Keywords}

Principal leadership;

Teacher work

discipline;

Teacher work

motivation;

Teacher performance

\begin{abstract}
The research aims to reveal the effect of 1.) Principal leadership; 2.) Teacher's work discipline; 3.) Teacher's work motivation; 4.) Principal leadership; 5.) Teacher's work discipline; and 6.) Teacher's work motivation simultaneously on the performance of the teachers of state senior high schools in Kulonprogo Regency. The research was ex-post facto research with the quantitative approach. The sampling technique used was a proportional stratified random sampling of the population of 385 teachers in the Kulonprogo Regency. Moreover, the sampling as much as 196 teachers are in Kulonprogo Regency. The validation is done through expert judgment and confirmatory factor analysis (CFA). The reliability was measured using Cronbach's Alpha $(\alpha)$. The data analysis used the Chi-Square statistical technique. The results are as follows: 1.) The principal leadership affects the performance of the teachers; 2.) The teacher's work discipline; 3.) The work motivation affects their performance; 4.) The principal leadership, teacher's work discipline; and 5.) Teacher's work motivation simultaneously on the performance of the teachers. The useful contribution of each variable is as follows: 1.) Principal leadership is $44,5 \%$; 2.) Teacher's work discipline is $66,6 \%$; and 3.) teacher's work motivation is $64,3 \%$. It means that principal leadership, teacher's work discipline, and teacher's work motivation affect teacher performance partially and simultaneously.
\end{abstract}

This is an open access article under the CC-BY-SA license.

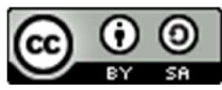

\section{INTRODUCTION}

The phenomenon of Teacher Competency Test (UKG) lately is fascinating to highlight. The Minister of Education stated that in November-December 2015, all teachers in Indonesia took part in the UKG. UKG is an assessment of teacher competency as part of teacher performance appraisal in the framework of teacher professional development and guidance based on teacher competency mapping. The low UKG results are a reflection of the low teaching performance of teachers in Indonesia, which is certainly related to the low Human Development Index (HDI) and the Education Development Index (EDI) in the United Nations Development Program (UNDP) and The United Nations Educational, Scientific and Cultural Organization (UNESCO). Considering the important role of the teacher's performance in the quality of education and human resources in Indonesia, it is natural to assume that the reality of the low HDI and the low quality of education in Indonesia is a result of the low performance of teachers.

Kulonprogo Regency shows that the HDI rate is $75,04 \%$, still below the DIY average of 76,32\% (Central Statistics Agency of Indonesia, 2011). Kulonprogo Regency is one of the five 
districts/cities in the Province of D.I. Yogyakarta locates at the westernmost point, with the western side boundary bordering Purworejo Regency, the eastern side bordering Sleman and Bantul districts, the north side bordering Magelang regency, and the south side bordering the Indian Ocean. A big question mark HDM Kulonprogo Regency is still below the average D.I. Yogyakarta. It is only natural that this raises the view that the reality of the low HDI in Kulonprogo Regency is a result of the low performance of teachers.

The low competency of teachers relates to professionalism. According to Wardhani (2017, p. 77) It is not easy for a person to be a professional. Certain qualifications are required for a professional to be said. The qualification relates to the ability of a teacher. According to Fitriani, Muniarti, and Usman $(2017$, p. 90) a professional teacher's competence is a set of abilities a teacher must have in order to carry out his or her teaching duties successfully. According to Cahyana (2010 p. 87) principle professional teachers are teachers who can perform their duties professionally. A professional teacher can be said formally with a certificate of educators. According to Daharti, Susilowati and Sutanto (2013, p. 81) recognition of teacher position as professional personnel is evidenced by certificate of educators.

The professionalism that teachers have is influential about performance. According to Pramesti and Muhyadi (2018, p. 44) teachers who have a good working motivation will certainly have a tendency to better ethos than teachers who lack work motivation. According to Kartini and Kristiawan $(2019$, p. 25) the teacher's spirit in teaching will influence the ability of the students. Unfortunately, some teachers actually have low motivation so that they do not run the maximum task. This suggests that the performance of teachers who are around the working environment of researchers is still lacking. According to Utari and Rasto (2019, p. 242) the improvement of teachers' work discipline is one of the crucial factors for the improvement of the teachers' performance that is much needed in carrying out quality education. There is no effort to perform a teacher's performance supervision. According to Sarifudin $(2019$, p. 432) the performance of teachers can be done through coaching the academic supervision results are excellent.

Related to the still low competence of teachers positively affects the low performance of teachers in the world of education in Indonesia. Teacher performance which expects to be able to boost the quality and relevance of education, in its implementation in the field depends on many factors that influence it and are interrelated, for example, the principal's leadership factors, welfare level, work climate, work motivation, discipline, teaching ability, personality and dedication, and development profession. Components in education units have their respective roles; for example, the principal as a leader, the teacher as the teaching staff, and students as an element of learning. Principal's leadership determines the quality, without good leadership, the process of improving quality can not be done and realized. The virtue of the principal's leadership influence is not merely in the form of instructions, but rather is a motivation or trigger that can inspire teachers and employees, so that initiative and creativity develop optimally to improve their performance.

The findings in the field, the principal's leadership, still shows suboptimal performance. It is indicated, among others, by the lack of school principals to conduct supervision activities. Teachers try to show their best performance in the planning and implementation aspects of learning only when visited. Furthermore, the teacher will return to work as usual, sometimes without careful preparation and enthusiasm and high enthusiasm. The principal, as a central figure, must realize that the formation of habits, attitudes, and behaviors in the context of school culture greatly influences school success. The development of a better and healthier school culture must begin with the leadership of the school principal (Raharjo \& Yuliana, 2016). However, the reality that is happening right now is that not infrequently, the leadership of the school principal makes the school atmosphere less conducive because of its inappropriate leadership model. Teacher enthusiasm sometimes decreases due to lack of motivation, poor teacher, and staff discipline due to the principal's leadership model that is not accepted by subordinates or because of low motivational factors.

Another factor that influences teacher performance is motivation. The motivation in question is to create a passion for work so that productivity increases. Meanwhile, the benefits of working with motivated people are that the work can appropriately be done. Work motivation is the key to success in performing well (creative, innovative, and useful). Teachers with high work motivation expect to be able to inspire their students to be motivated to learn. According to Utomo, Suminar, 
Hamidah, and Yulianto (2019, p. 72) The factors influencing motivational teaching teachers with regards to satisfaction needs. These needs relate to knowledge and skills. According to Mashari $(2019$, p. 2) knowledge and skills are very necessary to be supported by high motivation so that the work can be performed properly.

Findings in the field indicate that some teachers have low work motivation. The indication of the teacher's work motivation is still not optimal can also be seen from some teachers who leave the teaching task, leaving the empty hours without giving a substitute assignment. Good principal's leadership, high work motivation, good discipline will provide excellent teacher performance. The principal must always strive to foster teacher motivation by always communicating the policy to be made, involving the teacher in making decisions by accepting input or opinions from the teacher and giving appreciation to the teacher both materially and psychologically. Principals like this described as "self-directed learners" who realize that the duties of the principal cannot be managed by themselves, so they motivate and inspire others (staff) who are in the school organization. Effective school principals show interest in others and model sustainable learning. Based on the problems that have present. The primary purpose of this paper is to prove the influence of the principal's leadership, work discipline, and work motivation together to influence the performance of high school teachers in Kulonprogo Regency..

\section{METHOD}

This type of research is ex post facto, which is a study in which data on each variable is available. The study conduct at eleven high schools in Kulonprogo Regency, 11 (11) schools, namely Wates high school 1, Wates high school 2, Sentolo high school, Pengasih high school, Temon high school, Lendah high school 1, Lendah high school 2, Galur high school, Kokap high school, Samigaluh high school, Kalibawang high school, and Girimulyo high school. The study population was all teachers in state high schools in Kulonprogo Regency with 385 teachers. In comparison, the study sample consisted of 196 teachers. Data collection was done using techniques: interviews, documentation, questionnaires (questionnaires), and instruments.

The operational variables and definitions in this study include the dependent variable, namely teacher performance expressed by the $\mathrm{Y}$ variable. The independent variable includes the principal's leadership, which is stated by the variable $X-1$, Work discipline, which is stated by the variable $\mathrm{X}-2$, and work motivation, which is stated by variable $\mathrm{X}-3$. The variables in this study must be clearly understood. In order to avoid misunderstanding in interpreting the meaning of the variable, it is necessary to give a limited understanding of the existing variables. Teacher Performance is a condition that shows the ability of a teacher to carry out their duties in school. Data acquisition techniques regarding teacher performance obtain using a questionnaire. Principal's leadership is a global leadership that must be owned by the principal. Data acquisition techniques regarding principals' leadership competencies obtain using a questionnaire/questionnaire. Work Discipline is an action that educates someone to behave and behave provisions or guidelines set. Data acquisition techniques regarding work discipline were obtained using a questionnaire. Work motivation is one of the factors that encourage a person to act or do data acquisition techniques that motivate workers to obtain by using a questionnaire.

\section{Data Collection}

Primary data collection in this study carried out using techniques, including interviews. An interview is a technique to get data through direct communication with respondents (face to face relationships). The interview in this study uses to complete the information data both obtained through questionnaires and documentation. Documentation comes from the word document, which means written items used to find initial information before conducting further research. This data collection technique uses to find out the number of schools and the number of high school teachers in the Kulonprogo Regency. In this study, the authors used a data collection technique in the form of a questionnaire aimed at finding primary data. The questionnaire contained a list of questions related to teacher performance, principal leadership, work discipline, and work motivation. 


\section{Data Analysis}

The descriptive analysis used in this research is to describe the data with tables and histograms. The data analysis process carried out using SPSS. The description of interval data or data grouping calculates from the Sturges formula. The steps taken are determining the highest score and the lowest score, calculating the range of data, calculating the length of the class interval and arranging the class interval. The analysis carried out to analyze the influence of the principal's leadership, work discipline, work motivation on teacher performance. This analysis carried out after the data collected using a questionnaire has collected. The results of the influence test review at the significance value of $\mathrm{p}$. If $\mathrm{p}<0.05$, then there is a significant effect between the two variables tested, conversely if $p>0.05$, there is no significant effect between the two variables tested. Analysis of this research data using SPSS on a computer

\section{FINDINGS AND DISCCUSIONS}

Findings

\section{Characteristics of Respondents}

This study consisted of 196 samples, which were teachers in Kulonprogo High School 10. The following are the characteristics of respondents in the form of frequency and percentage values. The results of the calculation of the characteristics of respondents from the education variable, it was found that the majority of respondents in this study were diploma level (D3) as many as $2.6 \%$, bachelor (S1) as many as $88.8 \%$. Those who had post-graduate (S2) education were as many as $8.7 \%$. Some teachers are still in the process of continuing their studies at a higher level. It shows that teachers in the ten schools have a relatively good level of education. The status variable was found that the majority of respondents in this study that is with the status of being a government employee teacher as much as $92.3 \%$, the remaining teachers are still honorary staff as much as $7.7 \%$. It shows that teachers in ten schools have a permanent status and are bound by the service as civil servants.

Table 1. Educational Characteristics of Respondents

\begin{tabular}{cccc}
\hline No & Qualification & Frequency & Percentage (\%) \\
\hline 1 & D3 & 5 & 2,6 \\
2 & S1 & 174 & 88,8 \\
3 & S2 & 17 & 8,7 \\
& Total & 196 & 100,0 \\
\hline
\end{tabular}

Table 2. Characteristics of Respondents

\begin{tabular}{clccc}
\hline No & \multicolumn{1}{c}{ Status } & Freq & Percentage (\%) \\
\hline 1 & Honorary & & 15 & 7,7 \\
2 & Government employees & 181 & 92,3 \\
& & Total & 196 & 100,00 \\
\hline
\end{tabular}

\section{Results Categories and Variable Score Intervals}

The study used five categories, namely, very high, high, medium, low, very low. The category results are present in the frequency distribution table and pie chart (circle) of the distribution of the scoring trend (category). Variable identifiying is by the ideal mean (Mi) and the ideal standard deviation (Sdi) of each variable use.

The formula used is as follows:

$\mathrm{Mi}=1 / 2$ (highest score + lowest score)

$\mathrm{SDI}=1 / 6$ (highest score - lowest score) 
Based on data analysis techniques with descriptive methods, Azwar (2014, p.148) argues that raw scores can change into scaled standard values with the following details can be seen in Table 3.

Table 3. Categoryzed

\begin{tabular}{ll}
\hline Category & Formula \\
\hline Very High & $\mathrm{X}>\mathrm{M}+1,5 \mathrm{SD}$ \\
High & $\mathrm{M}+0,5 \mathrm{SD}<\mathrm{X} \leq \mathrm{M}+1,5 \mathrm{SD}$ \\
Medium & $\mathrm{M}-0,5 \mathrm{SD}<\mathrm{X} \leq \mathrm{M}+0,5 \mathrm{SD}$ \\
Low & $\mathrm{M}-1,5 \mathrm{SD}<\mathrm{X} \leq \mathrm{M}-0,5 \mathrm{SD}$ \\
Very Low & $\mathrm{X} \leq \mathrm{M}-1,5 \mathrm{SD}$ \\
\hline
\end{tabular}

The description of interval data or data grouping calculated from the Sturges formula. The number of interval classes is obtained by using the formula $\mathrm{k}=1+3.3 \log 196, \mathrm{k}=1+3.3(2,292)$ $=8.56$ and rounded up to 9 classes. The range of data obtains from the formula range $=$ (maximumminimum). While the width of the interval $\mathrm{I}=$ range $/ \mathrm{k}$, to find the interval width. The following will explain the categories and intervals of each variable can be seen in Table 4.

Table 4. Variable Categorical Teacher Performance

\begin{tabular}{cclcc}
\hline No & \multicolumn{1}{c}{ Interval } & Category & Freq & Percentage (\%) \\
\hline 1 & $187-210$ & Very High & 84 & $42,9 \%$ \\
2 & $170-186$ & High & 51 & $26,0 \%$ \\
3 & $154-169$ & Medium & 40 & $20,4 \%$ \\
4 & $138-153$ & Low & 12 & $6,1 \%$ \\
5 & $112-137$ & Very Low & 9 & $4,6 \%$ \\
& & & 196 & $100,0 \%$ \\
\hline
\end{tabular}

On the performance, variable obtained the majority of teachers in this study had the performance of teachers who fall into the very high category as much as $42.9 \%$. At least the performance of teachers in the very low category is $4.6 \%$. It shows that the teacher already has a pretty good performance. Teacher performance variable data can also see from the data distribution from grouping data. Based on the interval results, teacher performance data can be described in the following histogram in the Figure 1.

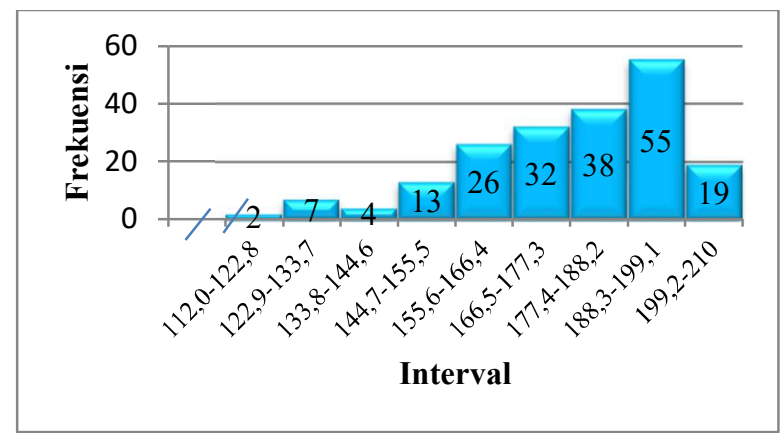

Figure 1. Teacher Performance Chart

Based on the results of the interval on the Figure 1, obtained an average teacher performance ranged from 188.3-199.1, which can be interpreted that the majority of teachers have a performance that has a range of data in a very high category, so it can be said that the teacher has a very high performance. On the principal's leadership variable, the majority of teachers in this study obtained leadership that is included in the very high category as much as $43.4 \%$. At least the teachers rate the 
leadership of the principal in the very low category, $4.6 \%$, meaning that this teacher assesses the leadership of the principal; it's very good. Based on the interval results, the principal's leadership data are depicted in the histogram as follows on the Figure 2.

Table 5. Principal Leadership Variable Category

\begin{tabular}{cclcc}
\hline No & Interval & Category & Freq & Percentage (\%) \\
\hline 1 & $314-350$ & Very High & 85 & 43,4 \\
2 & $289-313$ & High & 58 & 29,6 \\
3 & $264-288$ & Medium & 29 & 14,8 \\
4 & $239-263$ & Low & 15 & 7,7 \\
5 & $200-238$ & Very Low & 9 & 4,6 \\
& Total & & 196 & 100,0 \\
\hline
\end{tabular}

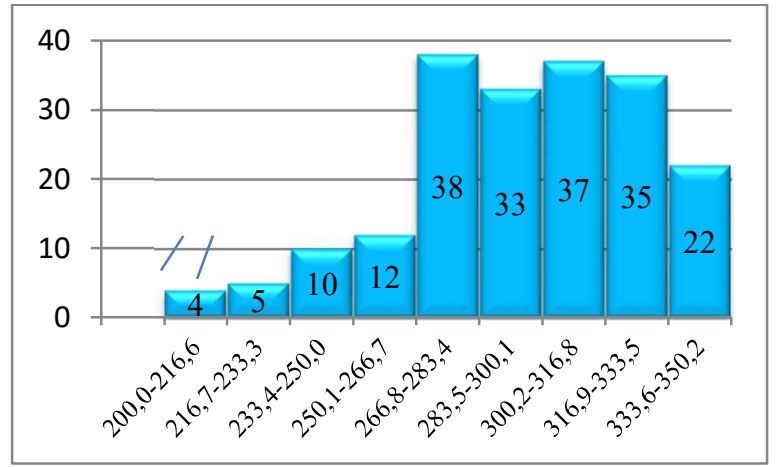

Figure 2. Principal Leadership Histogram Diagram

Based on the results of the interval, we obtained an average teacher rating on the leadership of principals that is 266.8-283.4. It means, which can provide an interpretation that the majority of teachers assess the leadership of principals who have a range in the very good category. So it can be said that the principal's leadership has very good leadership. In the work discipline variable, the majority of teachers have discipline in the very high category of $29.1 \%$. Work discipline can also see from the data distribution of data intervals on the Figure 3.

Table 6. Work Disciplinary Variable Categories

\begin{tabular}{cclcc}
\hline No & Interval & \multicolumn{1}{c}{ Category } & Freq & Percentage (\%) \\
\hline 1 & $124-133$ & Very High & 57 & 29,1 \\
2 & $117-123$ & High & 38 & 19,4 \\
3 & $110-116$ & Medium & 53 & 27,0 \\
4 & $102-109$ & Low & 20 & 10,2 \\
5 & $91-102$ & Very Low & 28 & 14,3 \\
& & Total & 196 & 100,0 \\
\hline
\end{tabular}

Based on the results of the interval in Figure 3, obtained an average teacher has a work discipline with a range of 109.8-114.4 that is 47 people. In addition, there are also respondents whose values are between 123.9-128.5 as many as 35 people, this can said the teacher has very good discipline. In the variable work motivation of teachers obtained the majority of teachers in this study had a motivation that is included in the very high category as much as $44.4 \%$. It shows that the teacher in this study had the very high motivation. 


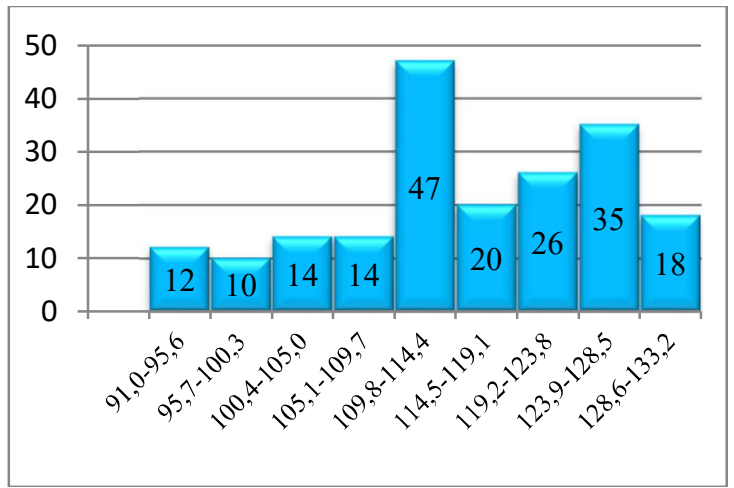

Figure 3. Work Discipline Histogram Diagram

Data on work motivation variables can also see as data distribution or data intervals following intervals from work motivation. Based on the results of the majority of work motivation intervals in the range of 124.9-132.5, which can interpret that the majority of teachers have work motivation in a very high category, so it can be said that teachers have very good work motivation. Work motivation histogram diagram can be seen in Figure 4.

Table 7. Categories of Work Motivation Variables

\begin{tabular}{ccccc}
\hline No & Interval & Category & Freq & Percentage (\%) \\
\hline 1 & $124-140$ & Very High & 87 & 44,4 \\
2 & $112-123$ & High & 57 & 29,1 \\
3 & $101-111$ & Medium & 41 & 20,9 \\
4 & $89-100$ & Low & 9 & 4,6 \\
5 & $71-88$ & Very Low & 2 & 1,0 \\
& & & 196 & 100,0 \\
\hline
\end{tabular}

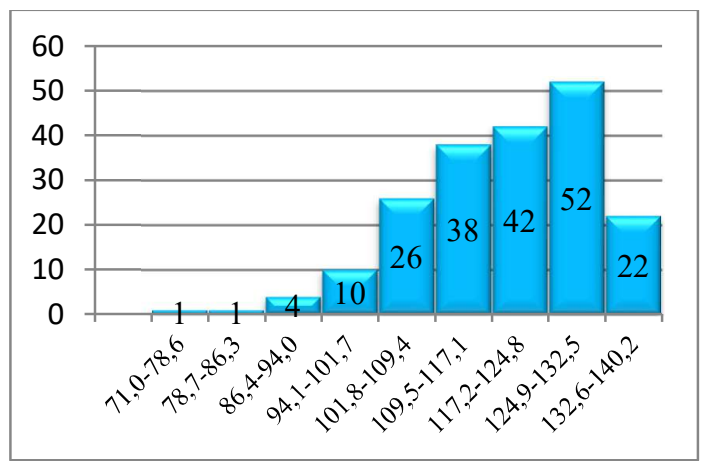

Figure 4. Work Motivation Histogram Diagram

\section{Chi-Square Analysis}

The influence of the principal's leadership, work discipline, work motivation on teacher performance was analyzed using the chi-square test. Explanation of the results of the chi-square test analysis uses to answer the following research hypotheses.

\section{Headmaster Leadership Variable}

Chi-square test to test the first hypothesis of the influence of principal school leadership on performance. Headmaster leadership variables have a significant effect on teacher performance. It obtains from the significance value of $0.035<0.05$. The coefficient of determination is 0.444 ; it can say that there is a positive influence of the leadership variable on teacher performance. The better 
the leadership of the principal, the better the teacher's performance will be. The tabulation results show that the existence of low principal leadership also results in low teacher performance of 4 people (40.0\%), as well as the presence of high school principal leadership, which also results in high teacher performance.

\section{Work Discipline Variable}

The independent variable will analyze by teacher performance. The second hypothesis about the effect of work discipline on teacher performance has a significant effect on teacher performance. It obtains from the significance value of $0.010<0.05$. The coefficient of determination is 0.665 , and it can say that there is a positive influence of the disciplinary variable on teacher performance. The better the discipline of work, the better the teacher's performance and vice versa, the lower the discipline of work, the teacher's performance is also low. The tabulation results show that low work discipline also results in low teacher performance of 4 people (40.0\%), as well as high work discipline also results in high teacher performance of 5 people $(50.0 \%)$.

\section{Work Motivation Variable}

The third hypothesis about the effect of work motivation on teacher performance explains as follows. Work motivation variables have a significant influence on teacher performance. It obtains from the significance value of $0.011<0.05$. The coefficient value is 0.643 , and it can say that there is a positive influence of the motivation variable on teacher performance. The higher the work motivation, the teacher's performance will also be higher, and vice versa, the lower the work discipline, the teacher's performance will also below. The tabulation results show that low work motivation also results in low teacher performance of 3 people $(30.0 \%)$, as well as high work motivation also results in high teacher performance of 6 people $(60.0 \%)$.

\section{Discussion}

\section{Effect of Principal Leadership on Teacher Performance}

Chi-square statistical test results obtained that the leadership variable has a significant effect on performance. It evidenced by the significance value of $0.035<0.05$. The coefficient of determination is 0.444 , and it can say that there is a significant favorable influence of leadership on teacher performance. The better the leadership of the principal, the better the teacher's performance will be. The school principal is a driving force in the school environment for teachers and staff who work, determining the direction of school policy, which will determine how school and education goals are generally realized. Principals are required to improve the effectiveness of teacher performance continuously. Effective principals' behaviors include displaying strong leadership and building relationships with fellow principals and teachers, providing direct support to teachers and students, empowering teachers and providing quality professional development opportunities for teachers to develop their abilities in the world of education, so that performance the teacher is getting more leverage. The teacher's performance can be interpreted as a condition that shows the ability of a teacher to carry out their duties at school and illustrates the making displayed by the teacher in or during learning activities. So that the better the leadership of the principal, the higher the performance of the school.

Principal's leadership in relation to school-based management is all the efforts made and results that can be achieved by the headmaster in implementing school-based management in his school to realize educational goals effectively and efficiently. A good headmaster's leadership will have an impact on better teacher performance. A good headmaster's leadership will provide clear guidance to the teacher, ultimately increasing teacher performance in educating. The results of this study are in line with the results of previous studies conducted by Darmansyah (2008) which showed the results of a significant influence of teacher professionalism and school leadership on the performance of teachers in state junior high schools in Brebes district with a determination coefficient $\left(R^{\wedge} 2\right)$ of 0.413 or $41,3 \%$. Regression $F$ value of 100,622 with a significance of 0,000 . The results of this study also indicate the influence of principal school leadership on teacher performance. 


\section{Effect of Work Discipline on Teacher Performance}

Chi-square statistical test results obtained that the discipline variable has a significant effect on performance. It obtains from the significance value of 0.010 , which is below 0.05 . The coefficient value of 0.816 can say that there is a significant positive effect of work discipline on teacher performance. The better the discipline of work, the better the teacher's performance will be. The work discipline variable is the most dominant variable affecting the teacher's performance than the work motivation and school leadership variables seen from the correlation coefficient. Discipline is a mental attitude that is reflected in the actions or behavior of individuals, groups, or communities in the form of adherence to the rules set by ethics, norms, and rules that apply in society for certain purposes. Work discipline in this study is intended to discipline the work of teachers in teaching or educating students, as well as discipline in completing school work. A disciplined teacher is defined as a teacher who always comes and goes home on time, does all his work well, complies with all applicable organizational rules and social norms.

A right attitude of discipline reflects the magnitude of one's sense of responsibility towards the tasks assigned to the teacher. It encourages enthusiasm for work, enthusiasm for work, and support the realization of school goals. Thus discipline is very important in efforts to improve teacher performance in schools. Work discipline is an attitude and behavior that intends to obey all organizational rules based on self-awareness to adjust to organizational regulations discipline related to how the teacher can manage both time and work. Teachers who have discipline will provide regularity in work so that it will give a good performance. Individual indiscipline can damage teacher performance at school. A teacher's work discipline is an act of someone to obey the rules that have mutually agree. This action done correctly and continuously will become a habit that is embedded in the teacher's behavior and will help achieve the specified work goals.

Teachers who have obedience to regulations such as timeliness, both starting lessons and completing class time will have an effect on the teacher to be able to properly manage class time. This will undoubtedly improve teacher performance for the better. The results of this study are in line with the results of previous studies conducted by Enni, Djasmi, and Sowiyah (2013), there is a strong influence between work discipline on teacher performance and the contribution of work discipline to teacher performance by $48.6 \%$, with a correlation coefficient $(r)=0.697$ and the coefficient of determination 0.486 .

\section{Effect of Work Motivation on Teacher Performance}

Chi-square statistical test results obtained that the motivation variable has a significant effect on performance. It obtains from the significance value of 0.011 , which is below 0.05 . The regression coefficient value of 0.802 can say that there is a significant positive effect of motivation on teacher performance. The better the motivation of the teacher, the better the teacher's performance will be. Work motivation is one of the factors that also determine a person's performance. Whether or not the influence of motivation on a person's performance depends on how much intensity the motivation is given. The difference in work motivation for a teacher is usually reflected in the various activities and even the achievements he achieves. Teacher work motivation is nothing but a process undertaken to move the teacher so that behavior can direct to real efforts to achieve the stated goals.

Teachers who have high work motivation will do more than just routine teaching tasks that will provide performance that exceeds expectations, so school productivity will increase. Work motivation is the key to success perform well (creative, innovative, and useful). Teachers with high work motivation are expected to be able to develop their competencies, which include pedagogical, professional, personality, and social competencies, whose estuary can inspire students to be motivated to learn. The results of this study support the results of previous studies conducted by Septiana, Ngadiman, and Ivada (2013) which shows the results of the influence of principal school leadership and work motivation on the performance of Wonosari high school teachers with a calculated $F$ value of $(20,574)$ greater than the $\mathrm{F}$ table value of $(3,120)$ with a probability of 0,000 . The magnitude of the influence of principal school leadership and work motivation on teacher performance is $34 \%$. 


\section{Multiple effect}

The overall chi-square test results can conclude that the principal's leadership, work discipline, and work motivation together influence the teacher's performance. Teacher performance is the ability of a teacher to carry out learning tasks at school. It is responsible for students under his guidance by increasing student learning achievement. Teacher performance involves all activities undertaken by a teacher in developing his mandate and responsibilities in educating, teaching, guiding, directing, and guiding students to reach the level of maturity and maturity. Types of performance include job performance and task performance.

The principal's leadership can also affect the performance of teachers in the school environment. The critical role of the principal as a leader is to make people, such as teachers and employees who come from different backgrounds. Different characters can unite to achieve school goals, and the principal must be able to create a conducive and competitive atmosphere and develop quality insights in all educational activities undertaken by teachers to improve performance. Principals who are able to position themselves when giving direction to their subordinates, maintain communication and receive input from teachers will make teachers, and staff valued at work will feel calm and comfortable so that the resulting maximum performance.

Teacher performance will be improved if the principal in his leadership always communicates the vision, mission, plans with the teacher together so that they are involved in their commitments, impose a high trust on teachers in carrying out their duties, are willing to provide guidance, direction or example to the teacher and are creatively creating a good work climate. The principal also not only instructs the teacher to carry out his ideas, but the principal also gives the teacher and staff the opportunity to make decisions whose purpose is for the common good. Another factor influencing teacher performance in addition to principal school leadership is work discipline. Good discipline reflects the magnitude of a person's sense of responsibility towards the task assigned to him. It encourages enthusiasm for work, enthusiasm for work and supports the realization of organizational, employee, and community goals. Thus discipline is very important in efforts to improve the performance of an organization or company. In other words, individual indiscipline can damage the performance of an organization or company.

Teachers who have high work motivation will do more than just routine teaching tasks that will provide performance that exceeds expectations, so school productivity will increase. Work motivation is the key to success in performing well (creative, innovative, and effective). Principals must also show examples, be open in their management, be patient, and attentive so that teacher performance includes: 1.) Skills in developing lesson plans; 2.) Skills in implementing lessons (teaching and learning process); and 3.) Skills in evaluating lessons can be improved. The results of this study are in line with the results of previous studies conducted by Suparno (2007) which show the results that: 1.) Work motivation, headmaster situational leadership, and teacher performance; 2.) Work motivation has a positive effect on teacher performance; 3 .) The principal's situational leadership positively influences teacher performance; and 4.) Work motivation and the principal's situational leadership will jointly influence teacher performance.

\section{CONCLUSION}

There is a significant influence of school principal leadership on the performance of high school teachers in Kulonprogo Regency with a significance value of 0.035 below 0.05 . The contribution of the principal's leadership to the teacher's performance is $(0.444)$ or $44.4 \%$. There is a significant influence of work discipline on the performance of state high schools in Kulonprogo Regency with a significance value of 0.010 below 0.05 . The amount of work discipline contribution to teacher performance is $(0.665)$, which is $66.5 \%$. There is a significant influence of work motivation on the performance of high school teachers in Kulonprogo Regency with a significance value of 0.011 , which is below 0.05 . The amount of work motivation contribution to teacher performance is (0.643), which is $64.3 \%$. There is an influence of school leadership, work discipline, work motivation together on the performance of high school teachers in Kulonprogo Regency. 
Practical implications in this study include several things, including the organizational structure of the principal's leadership school, which determines the quality. Without good leadership, the quality improvement process cannot realize. The virtue of the influence of the principal's leadership as a trigger that can inspire teachers and employees so that the initiative and creativity develop optimally to improve teacher performance. Good discipline reflects the magnitude of one's sense of responsibility for the tasks assigned to him. It encourages enthusiasm for work, enthusiasm for work, and supports the realization of school goals. Work discipline is very important in efforts to improve teacher performance. Work motivation is the key to success in performing well (creative, innovative, and effective). Teachers with high work motivation can develop performance in school, so they can inspire their students to be motivated to learn.

\section{REFERENCES}

Azwar, A. (2014). Reliabilitas dan validitas (4 ${ }^{\text {th }}$ ed.). Yogyakarta: Pustaka Pelajar.

Badan Pusat Statistik Republik Indonesia. (2011). Indeks Pembangunan Manusia Kabupaten Kulonprogo Tahun 2011.

Cahyana, A. (2010). Pengembangan kompetensi profesional guru dalam menghadapi sertifikasi. Jurnal Pendidikan dan Kebudayaan, 16(1), 85-91. Doi: http://dx.doi.org/10.24832/jpnk.v16i1.434

Daharti, R., Susilowati, I., \& Sutanto, H. A. (2013). Strategi peningkatan kompetensi guru dengan pendekatan analysis hierarchy process. JEJAK: Jurnal Ekonomi dan Kebijakan, 6(1), 80-92. Doi: https://doi.org/10.15294/jejak.v6i1.3750

Darmansyah, D. (2008). Kontribusi profesionalisme guru dan kepemimpinan kepala sekolah terhadap kinerja guru SMP negeri di kabupaten Brebe (Unpublished master's thesis). Universitas Negeri Semarang, Indonesia.

Dinas Pendidikan Kabupaten Kulonprogo. (2015). Peringkat UN SMA Negeri di Kabupaten Kulonprogo.

Enni, E., Djasmi, S., \& Sowiyah, S. (2013). Pengaruh disiplin kerja dan kepemimpinan kepala sekolah terhadap kinerja guru. Jurnal Manajemen Mutu Pendidikan, 1(1).

Fitriani, C., Muniarti, A. R., \& Usman, N. (2017). Kompetensi profesional guru dalam pengelolaan pembelajaran di MTs Muhammadiyah Banda Aceh. Jurnal Administrasi Pendidikan, 5(2), 88-95.

Kartini, D., \& Kristiawan, M. (2019). Pengaruh tunjangan profesi dan motivasi kerja terhadap kinerja guru. Kelola: Jurnal Manajemen Pendidikan, 6(1), 25-33. Doi: https://doi.org/10.24246/j.jk.2019.v6.i1.p25-33

Mashari, A. (2019). Kontribusi motivasi dan karakteristik guru terhadap kinerja guru di SMP Maarif Metro Lampung. Ahsanta Jurnal Pendidikan, 1(1), 1-10. Doi: https://doi.org/10.2503/ajp.v5i2.10

Pramesti, D., \& Muhyadi, M. (2018). Faktor-faktor yang mempengaruhi kinerja guru SMA. Harmoni Sosial: Jurnal Pendidikan IPS, 5(1), 43-56. Doi: https://doi.org/10.21831/hsjpi.v5i1.11854

Raharjo, S. B., \& Yuliana, L. (2016). Manajemen sekolah untuk mencapai sekolah unggul yang menyenangkan: Studi kasus di SMAN 1 Sleman Yogyakarta. Jurnal Pendidikan dan Kebudayaan, 1(2), 203-217.

Sarifudin, A. (2019). peningkatan kinerja guru dalam implementasi penilaian sistem SKS melalui supervisi akademik pengawas sekolah. Edukasi Islami: Jurnal Pendidikan Islam, 8(2), 417434. Doi: $\underline{\text { http://dx.doi.org/10.30868/ei.v8i2.539 }}$ 
Septiana, R., Ngadiman, N., \& Ivada, E. (2013). Pengaruh kepemimpinan kepala sekolah dan motivasi kerja terhadap kinerja guru SMP Negeri Wonosari. Jupe: Jurnal Pendidikan Ekonomi, 2(1), 107-118.

Suparno, S. (2007). Pengaruh motivasi kerja dan kepemimpinan situasional kepala sekolah terhadap kinerja guru SMP negeri di Kecamatan Pemalang Kabupaten Pemalang (Unpublished master's thesis). Universitas Negeri Semarang, Indonesia.

Utari, K. T., \& Rasto, R. Pengaruh disiplin kerja terhadap kinerja guru. Jurnal Pendidikan Manajemen Perkantoran (JPManper), 4(2), 238-245. Doi: https://doi.org/10.17509/jpm.v4i2.18019

Utomo, H. B., Suminar, D. R., Hamidah, H., \& Yulianto, D. (2019). Motivasi mengajar guru ditinjau dari kepuasan kebutuhan berdasar determinasi diri. Jurnal Psikologi, 18(1), 69-81. Doi: https://doi.org/10.14710/jp.18.1.69-81

Wardhani, F. R. (2017). Analisis kompetensi guru berbasis Uji Kompetensi Guru (UKG) pada guru Sekolah Menengah Kejuruan (SMK) bidang keahlian administrasi perkantoran di Surakarta tahun ajaran 2015/2016. Jurnal Informasi Dan Komunikasi Administrasi Perkantoran, 2(1), $75-84$. 